\title{
Creative Writing and the Study of Politics
}

Susan McWilliams, Pomona College

ABSTRACT Creative writing is not part of professional training in political science. Scholars in other fields, though, testify to the benefits of creative writing assignments, and my experiences teaching an undergraduate course on Politics and Literature suggest that there may be value in adding creative writing into certain political science courses. As with other forms of non-academic writing that political scientists identify as enriching, creative writing allows students to consider politics from multiple perspectives and expands their communicative powers. Working at the craft of storytelling-as opposed to abstract argumentation-can help students to think through key claims in contemporary political thought. Moreover, in this age of "alternative facts," doing creative writing in a politics course may help students hone a critical skill of citizenship: thinking about the news in terms of narrative. In this essay, I consider the advantages and challenges of bringing creative writing into the study of politics.

\section{A} few years ago, on something of a whim, I added an optional creative writing assignment to my upperlevel seminar course on Politics and Literature. I imagined that the assignment would interest only a small number of my students, and that the projects would be somewhat tangential to the themes of the course as a whole. I was surprised, then, when all but two students decided to pursue creative writing projects, and even more so when those projects resulted in more thoughtful work and more engaging in-class discussion than I'd ever seen in the course before.

I have kept the creative writing option on the course syllabus since. I am told that students consider the opportunity to do a creative writing project a hallmark of Politics and Literature, and that politics students often recommend the course to others because they found that project so enriching. In what is in my experience a stunning display of unanimity, every single student I have asked in my anonymous course survey says he or she is glad to have chosen to do a creative writing project-even though my students often report the project is hard. I have come to share my students' enthusiasm, finding that when I have a number of students engaged in and reflecting on works of creative writing, it enhances class discussion on questions that are central to the study of politics.

Needless to say, creative writing is not a traditional part of our training as political scientists. To my knowledge, it is rarely incorporated into our syllabi, but the experiences that my students and I have had in Politics and Literature suggest that there may be pedagogical value in adding creative writing components into

Susan McWilliams is an associate professor in the department of politics at Pomona College. She can be reached at susan.mcwilliams@pomona.edu. certain undergraduate courses in political science. As with other forms of non-academic writing that political scientists have identified as educationally enriching, creative writing gives students a chance to consider politics from the perspective of different actors and forces them to extend their writing capacities, expanding their communicative powers in ways that will help them both personally and professionally (Sherman and Weisman-Manor 2003; Pennock 2011). Like dramaturgical exercises, creative writing helps students develop empathy for different points of view, consider the role of symbolism in political life, and wrestle with political ambiguity (Freie 1997). Sociologists argue that creative writing assignments facilitate "sociological imagination," the capacity to think through the complicated social and cultural forces that invariably bear on politics (Bidwell 1995). Teachers in other academic fields increasingly have embraced creative writing in class as instructors realize how well it helps students develop as readers and critical thinkers (Everett 2005; Peary 2015).

In political science, working consciously at the craft of storytelling-as opposed to the craft of abstract argumentationcan help students to think through certain key claims in contemporary political thought, such as Hannah Arendt's dictum (1958) that all politics is storytelling and Martha Nussbaum's argument (2010) that literature is the bedrock of democracy because storytelling works to create the underlying feelings of empathy necessary for a healthy democratic polity. It may also be that in this age of "truthiness" and "alternative facts" in politics, doing creative writing in the context of a political science course helps students to hone what at least some scholars have argued is a critical skill of modern citizenship: to think about the news-about political journalism-in terms of narrative (Bird and Dardenne 2008). 
In this essay, I consider the advantages and challenges of bringing creative writing into the study of politics, particularly at the undergraduate level. I share here my perspective as someone who stumbled into giving this kind of assignment, who like most political scientists had no formal training in the teaching of creative writing, and who has learned along with my students what might be and what might not be accomplished by turning political scientists into creative writers. I also rely on anonymous surveys completed by all the students who took my Politics and
Students must choose their project type by the second week of the semester-they are not allowed to change tracks laterand they must be ready to speak about the general outlines of their project to their classmates by the third week of the course. Throughout the semester, I follow the students' progress in individual meetings and by reviewing drafts. I also encourage my students to engage in each other's work by setting up opportunities for peer editing and encouraging students to discuss their project ideas and questions in class. Finally, I make students commit to

\section{It may also be that in this age of "truthiness" and "alternative facts" in politics, doing creative writing in the context of a political science course helps students to hone what at least some scholars have argued is a critical skill of modern citizenship: to think about the news-about political journalism-in terms of narrative (Bird and Dardenne 20o8).}

Literature course in its most recent iteration, during the spring of 2016, and on relevant academic literature. ${ }^{1}$

\section{THE STORY OF THE CREATIVE WRITING ASSIGNMENT}

In my Politics and Literature course, my students read one literary work per week. The assigned readings include novels like Andre Dubus III's House of Sand and Fog, short stories like Shirley Jackson's "The Lottery," poems like those of Emily Dickinson's, and memoirs like Deanna Fei's Girl in Glass. The class is discussion-based and centers on questions about how authors use literature to explore political questions and expand political imagination. We explore both the possibilities and limitations of literature as a form of political communication and education.

For most of the years I've taught this course, my students wrote traditional academic essays to explore the themes we discuss in class. Those essays were sometimes quite successful, but the students' work often was disengaged-in most cases, I think, because my students were nearing graduation and did not see academic writing in their future. To see if I could generate at least marginally higher student interest, I started offering a creative writing option.

I give the students in Politics and Literature two basic options for their final course project. ${ }^{2}$ First, each student may complete a more traditional assignment: write a 20-page argumentative essay about the readings and themes of the course, write a 20-page serious literary analysis of a literary work not on the syllabus, or write three to four shorter argumentative essays that amount to 20 pages in total. Second, each student may undertake a project of creative writing that is minimally 20 pages in length, supplemented by a 10-page essay that reflects on the experience of creative writing and makes an argument about how that experience enhances, informs, or challenges the themes of the course. I emphasize to the students that if they elect to take on the creative writing project, I expect as much-if not moreintellectual seriousness from their projects and their reflective essays as I do from the more traditional assignments. For good measure, I repeatedly note that students who do the creative writing projects must produce at least 50\% more work, as measured by pages, than their peers who write argumentative essays. The stakes of the assignment are high; the final project is worth $25 \%$ of their grade in the course. reading aloud some portion of their work, in front of the entire class. Those facets of the assignment are the same, whether students are writing essays or creative pieces.

When I first thought all this up, I wanted to ensure that students were not choosing the creative writing assignment because they perceived it to be easier than the alternative. I also wanted to encourage my students to be serious about the choices they made. It is for those reasons-because the projects were high-stakes, long-term, and relatively public (in the sense of being vetted by and shared with classmates)-that I assumed my students, most of whom are upper-level politics majors, would default to the more traditional, argumentative essay assignment. I could not have been more wrong.

\section{THE NOVELTY OF THE CREATIVE WRITING ASSIGNMENT}

Why was I wrong in my prediction, and why do so many of my students choose to do creative writing? There are two consistent themes in the answers that students give when asked why they chose a creative writing project as opposed to the more traditional essay assignment. The first is that they wanted to try something new or different. As one student put it, "I've written so many analytical papers in four years here, and I was excited about the project of exploring creative expression." Said others: "I wanted to try something I'd never done before"; "I felt that it would put me out of my comfort zone the most"; "It was too unique an opportunity to pass up." The sentiment seemed particularly strong among upperclassmen, such as the senior who said he or she was "writing a thesis, so feeling very much OVER academic writing." 3

The second reason students tell me that they chose a creative writing project is summed up by the students who said, "I have always been interested in creative writing, even if not experienced, and this gave me an excuse to pursue it," or "I had an idea I wanted to explore and had never had a class that let me do it." 4 More than a few students said that they had been thinking about something for a long time, and the creative writing project was the first opportunity they found to explore that thought over an extended period, in a formal, academic setting.

What strikes me about both of those rationales is that before anything else, merely the novelty of the creative writing assignment engages student interest. Novelty has long been recognized as a generator of student interest and engagement, a recognition 
that has been affirmed by recent work in neuroscience (Glick 2011). And there is broad evidence that creative writing assignments in particular cause immediate spikes in student engagement, just as my students described, because it is "enactive"-that is, it compels them to explore their ideas in ways that feel more immediate and personal than in academic writing (Peary 2015). Among my students, even the fear that my grades for creative projects would be unusually arbitrary-that there were, as one student opined, "no real 'standards" for judging creative writing-was not significant enough to outweigh their desire to try something new, particularly near the end of their time in college, when most are not anticipating careers in the academy or in formal political science. 5 as evidenced by the student who said, "It was more personally fulfilling than any other college project."7

More specifically, my students report that they benefited from trying to consciously connect the personal to public through storytelling-which is precisely the act that Arendt locates at the heart of political judgment $(1958,50)$. Their language captures this in different ways. The creative writing assignment, one student said, "required me to take time to understand to what extent the personal is political." Another wrote, "I loved getting to see my writing ... through a political lens." A third, most directly ventriloquizing Arendt, said, "I learned about the politics of storytelling." 8 From my perspective as their teacher, having so many of them engaged in personally significant creative projects did

\section{And it is for those reasons-because the projects were high-stakes, long-term, and relatively public (in the sense of being vetted by and shared with classmates) - that I assumed my students, most of whom are upper-level politics majors, would default to the more traditional, argumentative essay assignment. I could not have been more wrong.}

To some degree, then, the sheer originality of the project captured my students' attention and caused them to work, at least by their own reports, harder than they would have worked on a traditional assignment. The challenge and excitement of novelty seems to have kept students interested throughout the semester, as is reflected in the comment from one student that "even though I found it more difficult than I imagined, I learned far more than I expected through the process of writing." In addition, for at least a couple students, there was a substantial payoff to exploring a new form of written expression: one said doing creative writing, "gave me faith in my abilities," while another said, "It expanded my view of my own abilities." ${ }^{\circ}$ From my perspective, that underlying sense of novelty led to a classroom where the energy and interest levels were visibly higher than when I taught Politics and Literature without a creative writing option. In that sense, my experience lines up with the conclusions of other scholars who see such assignments as a vehicle for student re-engagement (Morley 2007).

\section{ADVANTAGES OF THE CREATIVE WRITING ASSIGNMENT}

Of course, one can inject novelty into a political science course in any one of a number of ways without involving creative writing. When it comes to the specific advantages of the creative writing project within the context of political science, my students tend to highlight several ideas, all of which accord with my own sense of the course.

First, virtually all of my students said that doing creative writing feels more personal than doing analytic or argumentative writing. Their projects tend to be personal or otherwise reflective of their most passionate commitments-like the child of immigrants who wrote a series of poems, each of which captured the experiences of an immigrant family from a different generational perspective, or the student interested in education policy who tried, following Jean-Jacques Rousseau, to write a fictional model of an ideal education. Accordingly, a number of students said that their feeling of personal investment in the project motivated them to work harder than they might have worked otherwise, add vibrancy, enthusiasm, and insight to discussions about how we understand what it means for human beings to be political creatures, especially-in Aristotelian terms-the way in which our "politicalness" derives from the ways in which we are able to use language (Aristotle 1984).

Similarly, stemming from their experience of the creative writing project as a very personal experience, quite a few of my students emphasized that the project required them to work hard at the craft of what Nussbaum calls "empathetic imagination" (2010, 108). One student called the project "emotionally overwhelming" because it forced "an embracement of the person within political landscapes." Because "it was difficult to express myself in the way I wanted all the time," said a classmate, it was necessary "to really expand on and internalize some of my ideas up to this point in my life."9 Those kinds of experiences, which we discussed in class, seemed to help my students engage more immediately the recent and broadening literature in our discipline that situates empathy as central to democratic politics in particular (Clohesy 2013; Morrell 2010; Weber et al. 2011). They also seemed to connect more than my previous (pre-creative project) students to ideas about the importance of recognition in democratic politics, particularly as articulated in African American authors like Ralph Ellison who emphasize the difficulty of seeing and being seen in modern polities (1947; Turner 2012).

Finally, quite a few of my students said they thought that the practice of creative writing had made them better readers. A number of comments highlighted the development of what one student called, "a different relationship to the process of writing, and therefore reading." In most political science courses, said another, "We analyze," so as "to reverse roles and create new insight." Said another student, "Creating literature made me think about it from [a] diff[erent] perspective than that of a reader." Wrote another, "I learned a lot about the creative process, which helped me approach the texts we read." One student summed up the content of that learning by saying the project enabled him or her to better "think about intentionality and authorship." ${ }^{10}$ It is in some ways not surprising that the practice 
of authorship helps students to think differently or more clearly about authorship, but these responses have convinced me that the practice of authorship is key in a discipline where authority is a central concept-not to mention a discipline in which we ask our students to be good readers of texts, data, and societies.

Narrowing in on that theme, one student argued that the creative writing project "enabled me to see the power of words and narratives in our current political climate"-a sentiment echoed labor-intensive endeavor, for both professor and student. That intensive labor is both material (in terms of pages, rounds of revision, etc.) and intellectual (in terms of novelty, creativity, unfamiliarity, etc.). I have found that my creative writing assignment requires frequent conversation, both among students and between my students and me, to be truly beneficial. And without question, the success of the creative writing project in my Politics and Literature course owes to the fact that the course is a small

\section{Similarly, stemming from their experience of the creative writing project as a very personal experience, quite a few of my students emphasized that the project required them to work hard at the craft of what Nussbaum calls "empathetic imagination" $(2010,108)$.}

in many of the comments, like that of the student who wrote, "I learned so much about the world and myself through this project." ${ }_{11}$ While it has always been an aim of mine in Politics and Literature to encourage my students to think about the place of storytelling in contemporary politics, my experience is that having a creative writing component in class brings that thinking to the fore. Working on their own narratives, within the context of a class in politics, seems to attune students to what scholars have recognized as having a key place in political science-narrative (Patterson and Moore 1998).

\section{CHALLENGES OF THE CREATIVE WRITING ASSIGNMENT}

All that said, there are some evident challenges to assigning creative writing in a political science class. Perhaps most obviously, we political scientists are not practiced creative writers, and it can be daunting to offer feedback (not to mention grades) to students working on creative projects. I have tried to correct for my own deficiencies in a few ways: 1 ) by encouraging my students to seek feedback on their creative pieces at our college writing center, where there are specialists in creative writing; 2) by directing my students to colleagues and friends who are experienced creative writers; and 3) when grading, by focusing on evidence of effort and serious thought throughout the semester, rather than merely on the technical merits of the final project. I do have to devote more time and consideration to these projects than to the more traditional essays, simply because, as a scholar of politics, I do not evaluate them as automatically.

From my students' vantage point, the major disadvantage of the project seems to be that the creative writers have to work much harder-and give much more serious thought-to make intellectual connections between their writing and the course as a whole. "The disadvantage," said one, "was less opportunity to formally engage with theoretical concepts." Said another, doing a creative project made it harder to make "direct connection [s] to the books we read," in individual work. ${ }^{12}$ Many report that they had to put more work into the reflective essay than they had anticipated, that it was a constant challenge to keep their creative work in conversation with the course as a whole. From my perspective, the effort needed to rise to that challenge is probably part of what makes the students who do creative writing projects so thoughtful. But extra effort is indeed what it takes.

Both of these difficulties point to a greater underlying challenge of incorporating creative writing into political science: it is a (usually 12- to 20-person) seminar made up of upper-level students who tend to have some exposure to the central questions of political science and political theory in particular. There is strong evidence of the value of teaching creative writing in larger classrooms and to students at different levels of academic proficiency (Bishop and Starkey 20o6), but assignments in other classroom contexts would likely look different from my own.

I also think, given how much work the creative writing project can be, that it is successful in part because it is voluntary. My students self-select into the Politics and Literature course, and after that they have to volunteer to wade into the unfamiliar muddle of creative writing; that choice undoubtedly enhances their dedication to the project and their sense of accountability. For their part, my students always say they are glad for the choice, that I give them room to compose traditional argumentative essays if they wish-a few of them always do. I can imagine mandating a creative writing project on a much smaller scale, as a lower-stakes experiment in a political science course, but it is harder for me to imagine a project of this scope working as well if it were compulsory. In larger classrooms or with mandatory assignments, I suspect that shorter creative writing exercises would have much of the same value, without many of the challenges that a largerscoped project could bring.

\section{CONCLUSION}

Because of the nature of the discipline, exercises in creative writing will never be central to the pedagogy of political science. And yet, my experience in Politics and Literature suggests that there may be good reason to turn, on occasion, to creative writing in undergraduate courses. The practice of creative writing interests students because they perceive it as novel and personal, and it offers students the opportunity to connect to important (and often abstract) disciplinary conversations in new and immediate ways. It helps students consider politics through different perspectives, wrestle with the complications of political narrative, and makes them better readers and critical thinkers-all outcomes that help make our students more successful adults and effective citizens. Though creative writing is not a typical part of professional political science, it can help undergraduate students approach the study of politics.

\section{SUPPLEMENTARY MATERIAL}

To view supplementary material for this article, please visit https://doi.org/10.1017/S1049096517001275. 


\section{ACKNOWLEDGMENTS}

I would like to thank the students who took Politics and Literature at Pomona College in the spring of 2016, whose comments and conversations inform this essay: Bianca Cockrell, Madeline Colvin, Matt Dahl, Zoe Flavin, Audrey Glaser, Douglas Goldstein, Haley Goodman, Benjamin Higgs, Muhammad Jalal, Maya Kaul, Rebecca Marx, Madeline Minke, Margaret Munts, Maria Newman, Anna Schwab, Adam Starr, Adrián Suarez del Busto, and Elizabeth Wilcox. I am grateful also to the anonymous reviewers of this manuscript, whose advice markedly improved it.

\section{NOTES}

1. I assigned each student response a distinct letter, from A to M. I identify each response by letter in the notes below.

2. The assignment, as I presented it to students, is included as an online appendix to this article.

3. Student Responses A, E, F, I, M.

4. Student Response B, J.

5. Student Response A.

6. Student Responses B, F, I.

7. Student Response L.

8. Student Responses C, F, H.

9. Student Responses B, K.

10. Student Responses C, D, G, I.

11. Student Responses F, H.

12. Student Responses D, K.

\section{REFERENCES}

Arendt, Hannah. 1958. The Human Condition. Chicago: The University of Chicago Press.

Aristotle. 1984. Politics. Translated by Carnes Lord. Chicago: The University of Chicago Press.
Bidwell, Lee. 1995. "Helping Students Develop a Sociological Imagination Through Creative Writing." Teaching Sociology 23 (4): 401-6.

Bird, S. Elizabeth, and Robert W. Dardenne. 2008. "Rethinking News as Myth and Storytelling," in Handbook of Journalism, eds. Karin Wahl-Jorgenson and Thomas Hanisch. London: Blackwell.

Bishop, Wendy, and David Starkey. 2006. Keywords in Creative Writing. Logan: Utah State University Press.

Clohesy, Anthony M. 2013. Politics of Empathy: Ethics, Solidarity, Recognition. New York: Routledge.

Ellison, Ralph. 1947. Invisible Man. New York: Vintage, 1947.

Everett, Nick. 2005. “Creative Writing and English.” The Cambridge Quarterly 34 (3): 231-42.

Freie, John F. 1997. "A Dramaturgical Approach to Teaching Political Science.” PS: Political Science \& Politics 30 (4): 728-32.

Glick, Margaret. 2011. The Instructional Leader and the Brain: Using Neuroscience to Inform Practice. London: Sage.

Morley, David. 2007. The Cambridge Introduction to Creative Writing. Cambridge: Cambridge University Press.

Morrell, Michael E. 2010. Empathy and Democracy: Feeling, Thinking, and Deliberation. University Park, PA: The Pennsylvania State University Press.

Nussbaum, Martha. 2010. Not for Profit: Why Democracy Needs the Humanities. Princeton: Princeton University Press.

Patterson, Molly, and Kristen Renwick Moore. 1998. "Narrative in Political Science." Annual Review of Political Science 1: 315-31.

Peary, Alexandra. 2015. "The Pedagogy of Creative Writing Across the Classroom." In Creative Writing Pedagogies for the Twenty-First Century, eds. Alexandra Peary and Tom C. Hunley. Carbondale, IL: Southern Illinois University Press.

Pennock, Andrew. 2011. "The Case for Using Policy Writing in Undergraduate Political Science Courses.” PS: Political Science \& Politics 44 (1): 141-6.

Sherman, Daniel J., and Israel Weisman-Manor. 2003. "Get It in Writing: Using Politics to Teach Writing and Writing to Teach Politics.” PS: Political Science $\mathcal{E}$ Politics 36 (4): 755-57.

Turner, Jack. 2012. Awakening to Race: Individualism and Social Consciousness in America. Chicago: The University of Chicago Press.

Weber, Barbara, Eva Marsal, and Takara Dobashi, eds. 2011. The Politics of Empathy Berlin: Lit Verlag. 